Methodology article

\title{
REAL-TIME PCR ASSAYS FOR THE SPECIFIC DETECTION OF FIELD BALKAN STRAINS OF LUMPY SKIN DISEASE VIRUS
}

\author{
VIDANOVIĆ Dejan ${ }^{1 *}$, ŠEKLER Milanko ${ }^{1}$, PETROVIĆ Tamaš², DEBELJAK \\ Zoran $^{1}$, VASKOVIĆ Nikola ${ }^{1}$, MATOVIĆ Kazimir ${ }^{1}$, HOFFMANN Bernd ${ }^{3}$
}

${ }^{1}$ Department for Laboratory Diagnostic, Veterinary Specialized Institute „Kraljevo“, Kraljevo, Republic of Serbia; ${ }^{2}$ Virology Department, Scientific Veterinary Institute „Novi Sad“, Novi Sad, Republic of Serbia; ${ }^{3}$ Institute of Diagnostic Virology, Friedrich-Loeffler Institut, Greifswald-Insel Riems, Germany

(Received 10 November; Accepted 06 December 2016)

Lumpy skin disease (LSD) is an important disease of cattle which is included in the OIE list of notifiable terrestrial animal diseases because of its great economic importance. The etiological agent is the Lumpy skin disease virus (LSDV).

In the control of LSD attenuated strains of LSDV and SPPV are successfully used as vaccine strains in infected areas. In the case of vaccination policy, due to the possibility of mild or systemic post-vaccination reactions in vaccinated animals, the application of diagnostic procedures that will rapidly and specifically differentiate LSDV field strains from LSD vaccine virus strains are extremely important. Rapidity in diagnostics and disposal of infected animals is one of the key factors in the prevention of spreading the disease.

In the presented study we have described the development and validation of two realtime TaqMan-PCR assays for a rapid, sensitive and specific detection of the virulent field LSDV strain currently circulating in the Balkan Peninsula. Specificity for the field strain and exclusivity for vaccine strains was tested on 171 samples from naturally infected and vaccinated animals.

The results of this study show that both developed real-time PCR assays are more sensitive than the conventional nested PCR in detecting field LSDV strains thus enabling rapid and high-throughput detection of animals infected with field strains of LSDV.

In conclusion, both KV-2 and FLI real-time PCR assays described in this study are simple, rapid, sensitive and suitable for routine use in a diagnostic laboratory and have the potential to replace conventional nested gel-based PCR assays as the standard procedure for the detection of field strains of LSDV in clinical samples.

Key words: Lumpy Skin Disease virus, real-time PCR, DIVA diagnostic protocol, differentiation, field strain, vaccine strain

\footnotetext{
*Corresponding author: e-mail: vidanovic@vsikv.com
} 


\section{INTRODUCTION}

Lumpy skin disease (LSD) is an important disease of cattle which is characterized by fever, appearance of nodes on the skin, mucous membranes and internal organs, loss of appetite, debility, enlargement of lymph nodes, skin edema and sometimes death. The disease is included in OIE list of notifiable terrestrial and aquatic animal diseases. The economic importance of the disease is based on direct losses due to decrease in milk production, damage of the skin of animals, temporary or permanent sterility in bulls, and death of animals. The indirect losses caused by movement restrictions and trade of live animals and their products, costs for the veterinarians, disposal of carcasses, disinfection, vaccination, and so on are significant too. The morbidity range is from 3 up to $85 \%$. The mortality is generally low, ranging from $1-3 \%$ but can range up to $20 \%$ and higher [1-3]. Severity of the disease depends on the virus strain, age, race and immune status of cattle and may range from subclinical infection to death [4]. The recovery of animals with a severe clinical picture is slow and can last for some weeks or months.

The etiological agent is the Lumpy skin disease virus (LSDV). The virus has an outer envelope and typical poxvirus geomorphology. It belongs to the family Poxviridae, of the subfamily Chordopoxvirinae, in the genus Capripoxvirus [5]. Besides LSDV this genus includes sheep pox virus (SPPV) and goat pox virus (GTPV). All capripoxviruses are usually host specific. They are serologically indistinguishable and cause cross-immune protection [6,7]. Attenuated strains of LSD and SPPV are successfully used as vaccines in infected areas.

The genome of LSDV is $151 \mathrm{kbp}$ long with a central coding region bounded by identical $2.4 \mathrm{kbp}$-inverted terminal repeats and coded for 156 putative genes [8]. The capripox virus genomes are highly conserved; more than 95\% homology among LSD, SPPV and GTPV can be ascertained [9]. This homology can be used for the developing of PCR based methods for the detection of capripoxviruses. On the other hand, the identified sequence variability between LSDV, SPPV and GTPV occur in genes that likely determine virulence and host range [9] and were used for the developing of differential PCR protocols [10-16]. However, only a small number of tests are developed to distinguish strains within LSDV, especially the field strain from the vaccine strain $[17,18]$.

On the $07^{\text {th }}$ of June 2016, in the municipality of Bujanovac, populated place Ljiljance, after clinical suspicion, the first laboratory case of LSD in Serbia was confirmed at the Veterinary Specialized Institute Kraljevo. Due to the unfavorable epidemiological situation in the Southern parts of Serbia and in the neighboring countries, the decision was made to vaccinate cattle in the entire Republic of Serbia with Neethling vaccine strain, other measures for disease control were defined, also. In the case of the occurrence of the disease in unvaccinated herds euthanasia and safe removal of all cattle was performed, regardless of category, age and health status. After clinical manifestation and confirmation of the disease in a vaccinated herd, only clinically sick 
animals were euthanized and safely disposed. The rest of the herd was under the active supervision of the veterinary service.

Due to the possibility of mild or systemic post-vaccination reactions in vaccinated animals, the application of diagnostic procedures that will specifically differentiate LSDV field strain from vaccine strain was extremely important. At the time of occurrence of LSD in Serbia only a conventional [19] and a real-time PCR protocols [3] for the capripoxvirus detection were established. Because the real-time PCR protocol was more sensitive, specific, and easier to perform and interpret, it was mainly used in all examinations of material during the outbreak. For the differentiation of LSDV field and vaccine strain, the gene sequencing and the nested PCR protocol with RFLP analysis [17] was performed. The most important disadvantages of the nested PCR assay are the runtime of the entire protocol, usually 2 working days, a strong possibility of contamination especially in the case of testing a large number of samples and difficulties in interpreting the results.

The aim of this study was to design a reliable, high throughput real-time PCR assays for routine use in a diagnostic laboratory that will be able to specifically and sensitively detect the field strain of LSD virus in a short period of time. Development of such a protocol would enable the possibility of obtaining results in three hours after receiving the samples, thus shortening the time from sampling in the field until diagnosis, euthanizing and disposal of animals within 24 hours. Rapidity in diagnostics and disposal of infected animals is one of the key factors in the prevention of spreading and establishing the disease. The performance of the assays was compared with a previously published nested PCR assay developed for the discrimination of field and vaccine LSDV strain in Israel [17].

\section{MATERIAL AND METHODS}

\section{Samples}

The skin nodules have been shown to contain higher concentrations of virus $[1,3]$ and therefore these samples were preferred from clinically infected animals. Blood, nasal swabs and milk samples were also tested to determine if they can replace biopsy samples.

Specificity for field strain and exclusivity for vaccine strains was tested on 171 samples from naturally infected animals and vaccinated animals, from Serbia as well as from Montenegro. Naturally infected animals are considered as animals in which the field strain of the virus has been detected at least in one clinical specimen. The type of samples used in this study is shown in Table 1.

Also, diagnostic specificity and exclusivity of the assay was tested using one field strain of LSDV (Massalamia, Sudan), two field LSDV strains from Israel, Neethling vaccine strain (Lumpy skin Disease vaccine, OBP, South Africa) and SIS vaccine 
strain (Lumpyvax, MSD, South Africa) as well as strains from closely related viruses belonging to Capripoxvirus genus: SPPV (vaccine strain, Morocco - Rumanian strain) and GPPV (Gorgan, Iraq). DNA of LSDV field strain from Sudan, SPPV and GTPV strains were obtained from FAO/IAEA Animal production and Health Laboratory, Seibersdorf, Vienna, Austria. DNA of field LSDV strains from Israel were obtained from Kimron Veterinary Institute, Bet Dagan, Israel.

Table 1. Type of sample

\begin{tabular}{lc}
\hline Skin nodule biopsy & 55 \\
\hline Blood & 31 \\
\hline Nasal swabs & 17 \\
\hline Milk & 2 \\
\hline Flies & 1 \\
\hline Environmental swabs & 5 \\
\hline DNA of internal organs of cattle prior 2014 & 40 \\
\hline EDTA blood from vaccinated animals & 20 \\
\hline Total & 171 \\
\hline
\end{tabular}

\section{DNA extraction}

Extraction of DNA was performed on Kingfisher ml device (Thermo Fisher Scientific, Finland) using MagVet universal kit (LSI, Germany) with final elution volume of 100 $\mu l$. Preparation of a sample was as following: biopsy nodule samples were cut with a scalpel into small pieces and transferred to $10 \mathrm{ml}$ sterile tubes with glass beads and sterile phosphate-buffered saline (PBS) and homogenized on Vortex Genie 2 device (Scientific Industries, USA) for 5 minutes. Tubes were centrifuged one minute at 1000 $\mathrm{x} g$ and $200 \mu \mathrm{l}$ of supernatant was used for DNA extraction. DNA from blood, swabs and milk samples were extracted according to instructions from the extraction kit manufacturer.

\section{Primers and probes}

Primers and probes for KV-2 assay and the FLI assay were designed based on the 27 bp deletion in the extracellular enveloped virions gene (EEV) of LSDV vaccine strains compared to the field strains [17]. Five Serbian field strains and two vaccine strains were sequenced in that region and sequences were aligned using MEGA 6 software. Online software tool - Primer Blast was used for designing the primers that will span the mentioned region of EEV gene while the probe was designed manually.

Primers and probe for FLI assay were designed based on same property using published sequence information from GenBank and still unpublished sequence information from the field and vaccine strains of LSD circulating recently in Israel. All primers and probes designed for this study were synthesized by Metabion (Germany). 


\section{Determination of limit of detection (LOD)}

In order to determine $\mathrm{LoD}$ expressed in $\mathrm{TCID}_{50}$, serial tenfold dilutions of virus with known titer were made.

\section{Polymerase chain reaction}

For qPCR reactions Brilliant III ultra fast qPCR master mix (Agilent, USA) was used. Platinum Hot Start PCR Master Mix (2X) (Invitrogen, Lithuania) was used for nested PCR.

Mastermix reactions for KV-2 and FLI field strain qPCR were prepared in $25 \mu \mathrm{l}$ volumes with 2.5 of extracted viral nucleic acid, $0.2 \mu \mathrm{l}$ of each primer $(50 \mathrm{nM})$ and 0.1 $\mu \mathrm{l}$ probe $(50 \mathrm{nM}), 12.5 \mu \mathrm{l}$ of mastermix and $9.5 \mu \mathrm{H} 2 \mathrm{O}$.

Mastermix reaction for Bowden real-time protocol was as described [3].

Mastermix reactions and cycling conditions for nested PCR were as described in paper [17], except 35 cycles were performed in the second PCR reaction.

Real-time PCR was performed in two different thermal cyclers, AriaMX (Agilent) and Mx3000p (Stratagene) using following parameters: $95{ }^{\circ} \mathrm{C}$ for $3 \mathrm{~min}$, and $45 \times 95^{\circ} \mathrm{C}$ for $15 \mathrm{~s}$ and $60{ }^{\circ} \mathrm{C}$ for $30 \mathrm{~s}$.

Ariamx software was used for calculation of efficiency of the reaction, RSq (dR) and slope for both qPCR assays.

Nested PCR was performed in MJ Mini cycler (Bio-Rad, Singapoore). Electrophoresis of PCR product was performed on E-gel electrophoresis using $2 \%$ gel cassettes (Invitrogen, Israel) and visualization on GelDoc XR device (Bio-Rad, USA).

\section{Virus isolation and titration}

Isolation of LSDV was done by cultivation of skin nodes biopsy samples on MDBK cell culture line (ATCC CCL-22). Skin nodes tissues sampled by biopsy were cut by scissors in small pieces (about 1g), homogenized by TissueLyser LT (Qiagen, Germany) and diluted in PBS 1:10 (1g of tissue and $9 \mathrm{ml}$ of PBS) supplemented with antibiotics $(200 \mathrm{IU} / \mathrm{ml}$ penicillin; $100 \mu \mathrm{g} / \mathrm{ml}$ gentamicin and $5 \mu \mathrm{g} / \mathrm{ml}$ amphotericin B) to prevent bacterial growth. The skin nodes tissue homogenate was centrifuged at $2000 \mathrm{~g}$ for $15 \mathrm{~min}$ and $1 \mathrm{ml}$ of supernatant was used for inoculation of 24 hours old MDBK cell culture with $75 \%$ confluent cell layer in $25 \mathrm{~cm}^{2}$ tissue culture flask. Before inoculation, the cell culture growing medium was decanted from the flask and $1 \mathrm{ml}$ of tissue homogenate was added to the cell monolayer, gently shaking to distribute the inoculated material over the whole cell monolayer, and incubated for 1 hour at $37^{\circ} \mathrm{C}$. After the incubation $10 \mathrm{ml}$ cell growing medium (Eagle MEM, Sigma) with 10\% fetal calf sera (Capricorn Scientific, Germany) was added to the cells and the cell monolayer was microscopically observed daily for the development of the virus cytopathic effects $(\mathrm{CPE})$ in the next 7 days. The virus isolate named LSD-KV1-SRB was isolated in the 
first passage on MDBK cell culture. Two additional passages on MDBK cells were done in order to prepare the virus stock for further testing. The LSD-KV1-SRB virus stock was titrated on MDBK cell culture and the virus titre calculated by method of Reed and Muench [20] was $10^{6.0} \mathrm{TCID} / 50$ in $1 \mathrm{ml}$.

\section{RESULTS}

\section{Primers and probes developed in this study}

Primers and probe assays developed in this study were designed to detect Balkan field LSD strains. Primers and probe sequences, length of PCR products and positions are showed in Table 2.

Table 2. Primers and probe sequences, length of a PCR product and positions compared to Neethling 2490 complete genome AF325528.1

\begin{tabular}{|c|c|c|c|}
\hline $\begin{array}{l}\text { Primer/ } \\
\text { probe name }\end{array}$ & Primer/probe sequence $\left(5^{\prime}-3^{\prime}\right)$ & $\begin{array}{l}\text { PCR } \\
\text { product } \\
\text { length }\end{array}$ & $\begin{array}{l}\text { Position } \\
\text { in } \\
\text { genome }\end{array}$ \\
\hline KV-2 assay & & $113 \mathrm{bp}$ & \\
\hline LSD_KV_2_F & TGGGATGATAACAACGTTTATG & & $\begin{array}{l}116498- \\
116519\end{array}$ \\
\hline LSD_KV_2_R & ACATTGTCATCCGGTAATGTA & & $\begin{array}{c}116590- \\
116610\end{array}$ \\
\hline $\begin{array}{l}\text { LSD_KV2_Pro_ } \\
\text { field }\end{array}$ & $\begin{array}{l}\text { VIC- } \\
\text { TTACCACCTAATGATAGTGTTTATGATTTACC- } \\
\text { BHQ1 }\end{array}$ & & $\begin{array}{l}116522- \\
116553\end{array}$ \\
\hline FLI assay & & $121 \mathrm{bp}$ & \\
\hline LSD_FLI_F & GTGAAGAAAATTTAATTTGGGAC & & $\begin{array}{l}116481- \\
116503\end{array}$ \\
\hline LSD_FLI_R & СTCTATGTTTGAAACATTGTCA & & $\begin{array}{c}116623- \\
116602\end{array}$ \\
\hline LSD_FLI_Pro_Field & $\begin{array}{l}\text { FAM-ACCACCTAATGATAGTGTTTATGATTTAC- } \\
\text { BHQ1 }\end{array}$ & & $\begin{array}{r}116524- \\
116552\end{array}$ \\
\hline
\end{tabular}

\section{Limit of detection}

It was determined that the limit of detection is $0.2 \mathrm{TCID}_{50}$ per $\mathrm{ml}$ of both of the assays.

Efficiency of the qPCR reaction, RSq (dR) and slope for both qPCR assays were determined and shown in Table 3. 
Table 3. Efficiency of the qPCR reaction, RSq (dR) and slope for both qPCR assays

\begin{tabular}{lcccc}
\hline Assay & Target & Efficiency & RSq & Slope \\
\hline KV-2 assay & VIC & 103,2 & 0.992 & -3.248 \\
FLI assay & FAM & 102.9 & 0.987 & -3.255 \\
\hline
\end{tabular}

\section{Sensitivity and specificity}

The sensitivity of the designed qPCR protocols (KV-2 and FLI), and the nested PCR protocol [17] was evaluated on 111 samples from naturally infected and vaccinated animals, biopsy samples $(\mathrm{n}=55)$, cattle blood $(\mathrm{n}=31)$, nasal swabs $(\mathrm{n}=17)$, milk $(\mathrm{n}$ $=2)$, environmental swabs $(n=5)$ and flies samples $(n=1)$. The summarized results of comparative testing are shown in Table 4.

Table 4. The summarized results of comparative testing

\begin{tabular}{lcc}
\hline Assay & Positive & Negative \\
\hline Bowden qPCR & 98 & 13 \\
KV field strain & 69 & 42 \\
FLI field strain & 69 & 42 \\
Nested PCR & 88 & 23 \\
Nested PCR field strain after restriction & 61 & 27 \\
Nested PCR vaccine strain after restriction & 27 & 61 \\
\hline
\end{tabular}

In total, 98 samples out of 111 were found positive using Bowden qPCR assay specific for all capripoxviruses. Both KV-2 and FLI qPCR assays specific to virulent field strains of LSDV detected 69 samples as positive as field strains while nested PCR detected 61 samples as field strains positive. Also, two samples that were identified by nested PCR assay as vaccine strain were found positive with both qPCR assays as field strains positive too. Three samples that were positive with Bowden qPCR assay with Ct values higher than 35 were negative both using field strain qPCR assays and nested PCR assay. This might be due to the small viral load of the field strain that could not be detected by qPCR assays or small viral load of the vaccine strain that could not be detected by nested PCR so they are marked as inconclusive. As well, both qPCR assays detected a field strain from Sudan and two field strains from Israel as field strains positive samples.

The mean Ct value for biopsy samples was 23.8, for nasal swab samples 27.4 and for blood samples 29.6.

Additionally, 40 known LSDV negative samples were tested and all gave a negative result. Furthermore, the assays also did not amplify DNA from cattle vaccinated with 
Neethling vaccinal strain, Neethling and SiS vaccine, and also SPPV and GTPV strains of capripoxviruses.

\section{DISCUSSION}

Real-time PCR assays are quantitative, more sensitive, simpler and faster to perform compared to conventional PCR and nested PCR, and are therefore better suited to high throughput testing of samples [21]. Biopsy samples had the lowest $\mathrm{Ct}$ values which makes them the most suitable for testing. A number of real-time PCR methods for the detection of capripoxviruses have recently been described [3,11,18,22,23]. However, to our knowledge, until now no papers have been published describing TaqMan real Time PCR assays for the specific detection of the virulent field strain of LSDV.

The presented study describes the development and validation of two real-time TaqMan-PCR assays for the sensitive and specific detection of the virulent LSDV strain currently circulating in the Balkan countries. Since they are designed to detect only field strains of LSDV, the KV-2 and FLI qPCR assays are intended to be used in parallel or after the usage of qPCR assay that can detect both field and vaccine strains of LSDV [3]. That assay has already been validated [21] as a very sensitive assay designed for high-throughput testing.

In our study, both field qPCR assays detected six samples more than conventional nested PCR. The Ct values for the six samples which tested positive by the real-time assay and negative in gel-based nested PCR assay were higher than 34.5 suggesting that nested PCR was unable to detect due to its slightly lower analytical sensitivity compared to the real-time PCR assays. Furthermore, in two samples which were identified as LSDV vaccine strains by nested PCR followed by digestion with restrictive enzymes, also field strain genome of LSD could be detected by both qPCR assays. This indicates that nested PCR cannot always detect mixed infections of vaccine and field strains of the virus, especially if there is a much larger quantity of the vaccine strain genome in the sample. Based on the specific primers and probes used in the field strain specific real-time PCR assay (KV-2 and FLI) the amplification of field strain genomes will not be influenced by the vaccine strain.

The results of this study show that both real-time PCR assays using Brilliant III ultra fast qPCR mastermix (Agilent) were more sensitive than the conventional nested PCR in detecting field strains LSDV from recent outbreaks in Balkan countries.

The real-time assay showed no cross-reaction with related capripox viruses and a diagnostic specificity of $100 \%$ when tested against a panel of LSDV negative samples or samples from non-infected vaccinated animals.

In conclusion, both KV-2 and FLI real-time PCR assays described in this study are simple, sensitive and specific thus enabling the rapid, high-throughput testing for field strains of LSD. The assays have the potential to replace conventional nested gel-based PCR assays as the standard procedure for detection of field strains of LSD in clinical 
samples. This might especially be the case in the countries where an outbreak occurs and a vaccination strategy is applied. Although the assays were evaluated mostly on field Balkan LSDV strains, it was found that they could also be used for the detection of field strains from Israel and Sudan. However, further validation of these assays with field strains isolated in other parts of the world will be necessary to ascertain its usability as a diagnostic tool.

\section{Acknowledgments}

Part of this study was conducted within Projects III41010 and TR31084 funded by the Serbian Ministry of Education, Science and Technological development.

The authors want to thank: Giovanni Cattoli, Charles Lamien and Ivancho Naletoski from FAO/IAEA Animal production and Health Laboratory, Seibersdorf, Vienna, Austria, for kindly providing LSDV, SPPV and GTPV DNA; Dejan Laušević, Radoš Miković and Bojan Adžić from Diagnostic Veterinary Laboratory Podgorica, Montenegro, for kindly providing LSDV DNA from Montenegro; Oran Erster from Kimron Veterinary Institute, Bet Dagan, Israel for kindly providing LSDV DNA from Israel.

\section{Authors' contributions}

DV and $\mathrm{BH}$ participated in experimental design, laboratory testing, results analysis, collection of literature data and preparation of manuscript. MŠ carried out laboratory testing and results analysis. TP participated in isolation of the virus. ZD and NV collected of the samples. KM participated in laboratory testing.

\section{Declaration of conflicting interests}

The author(s) declared no potential conflicts of interest with respect to the research, authorship, and/or publication of this article.

\section{REFERENCES}

1. Babiuk S, Bowden TR, Parkyn G, Dalman B, Manning L, Neufeld, J. Embury-Hyatt C, Copps J and Boyle DB: Quantification of lumpy skin disease virus following experimental infection in cattle. Transboundary and Emerging Diseases 2008, 55(7):299-307.

2. Babiuk S. Bowden TR. Boyle DB. Wallace DB. Kitching RP: Capripoxviruses: an emerging worldwide threat to sheep, goats and cattle. Transboundary and Emerging Diseases 2008, 55:263-272.

3. Bowden TR, Babiuk SL, Parkyn GR, Copps JS, Boyle DB: Capripoxvirus tissue tropism and shedding: A quantitative study in experimentally infected sheep and goats. Virology 2008, 371(2):380-93.

4. Carn VM \& Kitching RP: The clinical response of cattle experimentally infected with lumpy skin disease (Neethling) virus. Archives of Virology 1995, 140: 503. 
5. International Committee on Taxonomy of Viruses, Virus Taxonomy: 2015 Release, EC 47, London, UK, July 2015.

6. Babiuk S, Bowden TR, Parkyn G, Dalman B, Hoa DM, Long NT, Vu PP, Bieu do X, Copps J, Boyle DB: Yemen and Vietnam capripoxviruses demonstrate a distinct host preference for goats compared with sheep. The Journal of General Virology 2009, 90:105-114.

7. Davies FG: Lumpy skin disease, an African Capripoxviruses Disease of Cattle. British Veterinary Journal 1991;147:489-502.

8. Tulman ER, Afonso CL, Lu Z, Zsak L, Kutish GF, Rock DL: Genome of Lumpy Skin Disease Virus. Journal of Virology 2001, 75(15):7122-7130.

9. Tulman ER, Afonso CL, Lu Z, Zsak L, Sur JH, Sandybaev NT, Kerembekova UZ, Zaitsev VL, Kutish GF, Rock DL: The genomes of sheeppox and goatpox viruses. Journal of Virology 2002, 76:6054-6061.

10. Heine HG. Stevens MP. Foord A.J. Boyle DB: A capripoxvirus detection PCR and antibody ELISA based on the major antigen P32, the homolog of the vaccinia virus H3L gene. Journal of Immunological Methods 1999. 227:187-196.

11. Haegeman A, Zro K, Vandenbussche F, Demeestere L, Van Campe W, Ennaji MM, De Clercq K: Development and validation of three Capripoxvirus real-time PCRs for parallel testing. J Virol Methods 2013, 193(2):446-51.

12. Hosamani M, Mondal B, Tembhurne PA, Bandyopadhyay SK, Singh RK \& Rasool TJ: Differentiation of sheep pox and goat poxviruses by sequence analysis and PCR-RFLP of P32 gene.Virus Genes 2004, 29(1), 73-80.

13. Tuppurainen ES, Venter EH, Coetzer JA: The detection of lumpy skin disease virus in samples of experimentally infected cattle using different diagnostic techniques. The Onderstepoort Journal of Veterinary Research 2005, 72:153-164.

14. Stram Y, Kuznetzova L, Friedgut O, Gelman B, Yadin H, Rubinstein-Guini M: The use of lumpy skin disease virus genome termini for detection and phylogenetic analysis. J Virol Methods 2008, 151(2):225-9.

15. Lamien CE, Le Goff C. Silber R. Wallace DB, Gulyaz V, Tuppurainen E, Madani H, Caufour P, Adam T, El Harrak M, Luckins AG, Albina E, Diallo A: Use of the capripoxvirus homologue of vaccinia virus $30 \mathrm{kDa}$ RNA polymerase subunit (RPO30) gene as a novel diagnostic and genotyping target: development of a classical PCR method to differentiate goat poxvirus from sheep poxvirus. Vet. Microbiol 2011, 149:30-39.

16. Venkatesan G, Balamurugan V, Yogisharadhya R, Kumar A, Bhanuprakash V: Differentiation of sheeppox and goatpox viruses by polymerase Chain reaction-restriction fragment length polymorphism. Virol Sin 2012, 27(6):353-9.

17. Menasherow S, Rubinstein-Giuni M, Kovtunenko A, Eyngor Y, Fridgut O, Rotenberg D, Khinich Y, Stram Y: Development of an assay to differentiate between virulent and vaccine strains of lumpy skin disease virus (LSDV). J Virol Methods 2014, 199:95-101.

18. Menasherow S, Erster O, Rubinstein-Giuni M, Kovtunenko A, Eyngor E, Gelman B, Khinich E, Stram Y: A high-resolution melting (HRM) assay for the differentiation between Israeli field and Neethling vaccine lumpy skin disease viruses. J Virol Methods 2016, 232:12-5.

19. Ireland DC, Binepal YS: Improved detection of capripoxvirus in biopsy samples by PCR. J. Virol. Methods 1998, 74: 1-7.

20. Reed LJ, Muench H: A simple method of estimating fifty per cent endpoints. Am J Hyg 1938, 27:493-497.

21. Stubbs S, Oura CA, Henstock M, Bowden TR, King DP, Tuppurainen ES: Validation of a high-throughput real-time polymerase chain reaction assay for the detection of capripoxviral DNA. J. Virol. Methods 2012, 179 (2) 419- 422. 
22. Balinsky CA. Delhon G. Smoliga G. Prarat M. French RA. Geary SJ. Rock DL. Rodriguez LL: Rapid preclinical detection of sheeppox virus by a real-time PCR assay. Journal of Clinical Microbiology 2008, 46:438-442.

23. Lamien CE, Lelenta M, Goger W, Silber R, Tuppurainen E, Matijevic M, Luckins AG, Diallo A: Real time PCR method for simultaneous detection, quantitation and differentiation of capripoxviruses. J. Virol. Methods 2011, 171:134-140.

\title{
REAL-TIME PCR TESTOVI ZA SPECIFIČNU DETEKCIJU TERENSKIH BALKANSKIH SOJEVA VIRUSA BOLESTI KVRGAVE KOŽE
}

\author{
VIDANOVIĆ Dejan, ŠEKLER Milanko, PETROVIĆ Tamaš, DEBELJAK \\ Zoran, VASKOVIĆ Nikola, MATOVIĆ Kazimir, HOFFMAN Bernd
}

Bolest kvrgave kože (Lumpy skin disease, eng. - LSD) je važno oboljenje goveda koje se zbog svog velikog ekonomskog značaja nalazi na OIE listi bolesti obaveznih za prijavljivanje. Etiološki agens je virus bolesti kvrgave kože goveda (Lumpy skin disease virus, eng. - LSDV).

U kontroli LSD uspešno se kao vakcina u zaraženim područjima koriste atenuirani sojevi LSDV i Sheep pox virus, eng. - SPPV. U slučaju politike sprovođenja vakcinacije, zbog mogućnosti blagih ili sistemskih reakcija nakon vakcinacije kod vakcinisanih životinja, primena dijagnostičkih metoda koje će brzo i specifično razlikovati terenske sojeve LSDV od vakcinalnih je izuzetno važna. Brzina u dijagnostici i neškodljivom uklanjanju zaraženih životinja su jedan od ključnih faktora u prevenciji širenja bolesti.

U predstavljenom radu opisali smo razvoj i validaciju dva real time TaqMan PCR testa za brzu, osetljivu i specifičnu detekciju virulentnih terenskih sojeva LSDV koji trenutno kruže na Balkanskom poluostrvu. Specifičnost za terenske sojeve $\mathrm{i}$ isključivost za vakcinalne sojeve je ispitana na 171 uzorku prirodno zaraženih i vakcinisanih životinja.

Rezultati ovog istraživanja pokazuju da su real-time PCR testovi bili osetljiviji od konvencionalnog nested PCR u otkrivanju terenskih sojeva LSDV čime se omogućava brzo ispitivanje terenskih sojeva LSD visoke propusne moći.

Kao zaključak, oba real-time PCR testa, KV-2 i FLI, koja su opisana u ovom radu su jednostavna, osetljiva, i pogodna za rutinsku upotrebu u dijagnostičkim laboratorijama i imaju potencijal da zamene konvencionalni nested PCR test, kao standardni postupci za otkrivanje terenskih sojeva LSDV u kliničkim uzorcima. 